\title{
QUALITY EVALUATION OF CASSAVA-PIGEON PEA COMPOSITE FLOUR AND THE COOKIES
}

\author{
Ihemeje, Austin ${ }^{1}$, Uneanya, Genevieve Chioma ${ }^{2}$, Odimegwu, Nkiru Euphresia ${ }^{3}$ \\ andEchefu, Eunice Ogechi ${ }^{4}$ \\ 1 \& 4: Dept. of Food Science and Technology, Imo State University, Owerri \\ 2: Dept. Food Science and Technology, Federal Polytechnic Nekede, Owerri \\ 3: Dept. of Food Science and Technology, Federal University of Technology, Owerri \\ Corresponding author: Ihemeje, Austin.E-mail: ihemeje.austin@yahoo.com
}

\begin{abstract}
Cassava flour $(C F)$ and pigeon pea flours $(P F)$ were respectively produced and blended in the ratios of 100:0, 95:5, 90:10, 85:15 and 80:20. The flour blends were subjected to proximate, functional and anti-nutrient analysis after which they were used to produce cookies. The sensory and physical characteristics were analyzed. The proximate analysis of the flour blends showed protein (2.19-7.25\%), fat (1.09-1.91\%), crude fibre (3.76-4.66\%), ash (1.49-2.52\%), moisture (10.58-11.03\%) and carbohydrate (73.50-79.99\%). The result indicated that the incorporation of pigeon pea flour led to significant $(p<0.05)$ increase in protein, fat and ash content of the flours but reduced the moisture and carbohydrate contents. The range of anti-nutrients in the flour samples were phytate (0.253-0.321\%), phenol(0.078-0.107\%), tannin(0.130-0.243\%), trypsin inhibitor(0.39-1.30TIU/mg) and hydrogen cyanide (2.04-3.18mg/kg). There was significant $(p<0.05)$ decrease in the level of anti-nutrients with increase in the addition of pigeon pea flour except for trypsin inhibitor which increased with addition of the pigeon pea flour. The result for functional properties of the flour samples revealed that bulk density ranged from 0.531 $0.608 \mathrm{~g} / \mathrm{ml}$, water and oil absorption capacities ranged from $1.79-2.11 \mathrm{~g} / \mathrm{g}$ and $1.83-2.11 \mathrm{~g} / \mathrm{g}$ respectively. Swelling capacity and foaming capacity were each in the range of $1.68-1.96$ and 11.71-14.64\% respectively. Sensory analysis of the cookies produced from the flour blends proved that cookies produced from $5 \%$ and $10 \%$ levels of substitution with pigeon pea flour had high overall acceptability compared to the other samples.
\end{abstract}

Key words: Cassava, pigeon pea, composite flour, cookies, nutrient, antinutrient https://dx.doi.org/10.4314/jafs.v15i2.5

Journal of the Faculty of Agriculture and Veterinary Medicine, Imo State University Owerri website: wwwajol.info 
Journal of Agriculture and Food Sciences

Volume 15 Number2, October 2017 pp.

Journal of the Faculty of Agriculture and Veterinary Medicine, Imo State University Owerri website: wwwajol.info 


\section{INTRODUCTION}

Increased urbanization in Nigeria and other African countries has been changing the food habits and preferences of people towards convenience foods. Bread, biscuits, cookies, buns and other baked products are some of the foods now relished by the population (Oyewoleet al., 1996). Cookies contain digestive and dietary principles of vital importance (Kulkarni, 1994).

Cassava (Manihotesculenta) is a root crop rich in starch. Its root is tapered with a firm homogenous flesh encased in a detachable rind about $1 \mathrm{~mm}$ thick, rough and brown on the outside. It is a versatile crop which can be processed into a wide range of products such as starch, flour, beverages, cassava chips, etc. Cassava flour which is one of the major products of cassava root is traded in the world food market. Cassava flour has continued to find wider applications in food, feed and chemical industries (Balagopalanetal., 1988) and one of the most popular uses of cassava flour worldwide is in the manufacture of baked products (Shittuet al., 2007).

Pigeon pea (Cajanuscajan) is a draught tolerant and easy to cultivate crop. It is known as "fiofio" in South Eastern Nigeria and "waken" in Northern Nigeria (Enwere, 1998). It is a woody, short-lived perennial crop (although it is sometimes grown as an annual). It may reach 1 to $4 \mathrm{~m}$ in height. The flowers are yellow and the pods contain 3 to 4 seeds which may be white, grayish, red, brown, purplish, or speckled, with a white hilum. It is used in more diverse ways besides its main use as dhal (a main dish in India made of long-cooked pulses). Its tender green seeds are used as vegetable, crushed dry seed as animal feed, green leave as fodder, stems as fuel wood and to make hut baskets, etc. It is one of the lesser known legumes in Nigeria and much is not known of its nutritional value. Abdel et al. (2010) reported that the crude protein content of pigeon pea is $21 \%$. So it could be a good source of protein for low income earners. Pigeon pea contains a reasonable amount of all dietary essential minerals (Torres et al., 2007).

Composite flour is a mixture of flours intended to replace wheat flour totally or partially in bakery and pastry products (Shittuet al., 2007). Composite flour has a few advantages in developing countries as it aids in the saving of hard currency, leads to overall use of domestic agricultural products and provides a better supply of protein for human nutrition (Berghofer, 2000; Bugusu et al., 2001). This work was aimed at the production of cookies using entirely alternative raw materials (cassava and pigeon pea) other than wheat flour.

\section{MATERIALS AND METHODS}

\section{Preparation of cassava and pigeon pea flours}

Cassava tubers were peeled, washed and grated with a cassava grater. The resulting mash was dewatered and sun-dried for 2 days after which it was milled with an attrition mill and sieved with a $40 \mathrm{~mm}-\mathrm{mesh}$ sieve. 
The pigeon pea flour was produced as described by Echendu et al. (2004). The flours were blended in the ratios of 100:0, 80:20, 60:40, 20:80 and 0:100 respectively packaged in cellophane bags and stored at room temperature prior to laboratory analysis and cookies production.

\section{Preparation of cookies}

After mixing the ingredients (Table 1), the dough was kneaded to uniform thickness of $0.25 \mathrm{~cm}$ and cut to a diameter of $4.6 \mathrm{~cm}$. The cookies were baked for $15 \mathrm{~min}$ at $185^{\circ} \mathrm{C}$ in an oven, cooled, packaged in polyethylene bags and stored at room temperature.

\section{Proximate analysis of flour samples}

The moisture, crude protein, fat, ash, fibre and carbohydrate content were determined according to AOAC (2010).

\section{Analysis of functional properties of flour samples}

The Bulk density, swelling capacity and foaming capacity were respectively determined following the methods of Giami (1993), Ukpabi and Ndimele (1990) and Onwuka (2005), while water and oil absorption capacities were each determined according to Abbey and Ibeh (1998) and Onwuka (2005).

\section{Determination of anti-nutrient contents of flour samples}

Phenol, tannins, trypsin inhibitor activity, hydrogen cyanide and phytate were evaluated according to AOAC (2010).

\section{Physical analysis of cookies}

The weight and diameter of the baked cookies were determined using weighing balance and calibrated ruler respectively. The spread ratio was determined using the method described by Gomez et al. (1997).

\section{Sensory Evaluation}

Cookies samples were presented to 30 panelists. The panelists were instructed to evaluate appearance, taste, texture, crispiness and general acceptability using a hedonic scale ranging from dislike extremely (1) to like extremely (9).

\section{Statistical Analysis}

Data obtained was analysed using analysis of variance (ANOVA) while Tukey test was applied for separation of means. 


\section{RESULTS AND DISCUSSION \\ Proximate composition of cassava-pigeon pea flour samples}

Sample A (100\% cassava flour) had a low protein content (2.19\%) compared to the composite flour blends (Table 2). There were significant $(\mathrm{p}<0.05)$ increase in the crude protein content of the flour blends except at $5 \%$ level of substitution with the pigeon pea flour. It was observed that cassava flour is low in fat $(1.09 \%)$ and the incorporation of pigeon pea flour increased the fat content of the blends. The fibre content of sample $\mathrm{A}(4.66 \%)$ was significantly $(\mathrm{p}<0.05)$ higher than the other samples. This could be because cassava is known to be high in carbohydrates such as cellulose, starch and hemicellulose. The ash content of the flour samples ranged from $1.49 \%$ to $2.52 \%$. The result showed that the ash content of the flour samples increased significantly $(\mathrm{p}<0.05)$ on blending with higher ratios of pigeon pea flours. The moisture content of the blends decreased with incorporation of pigeon pea flour. This could be due to the more incorporation of pigeon pea flour which has lower water absorption capacity than cassava flour. Samples A and E respectively have the highest $(79.99 \%)$ and least $(73.50 \%)$ carbohydrate content. Addition of pigeon pea flour (a legume) led to the reduction in carbohydrate content of the blends. Oluet al. (2011) reported a similar trend of decrease in carbohydrate content as a result of supplementing wheat flour with legume (soya bean)flour.

Functional properties of the flour blends: There was significant increase in the foaming capacity of the flour samples as incorporation of pigeon pea flour increased (Table 3). But the reverse was the cases of bulk density, water, oil absorption and swelling capacity. The foaming capacity of the flour samples ranged from $11.71-14.64 \%$. The result is statistically significant $(\mathrm{p}<0.05)$ for samples A, B and C. The highest foam capacity $(14.64 \%)$ was observed for sample E followed by sample D (14.31\%) while the lowest (11.71\%) was observed from sample A. This could be a reflection of the protein contents of the samples. The flour blends were found to be of low bulk density. Bulk density influences the packaging and transportation of materials. Therefore the low bulk density of the samples implied that they can be packaged and transported with ease comparable to other flours. Water absorption capacity is the ability of a substance to combine with water under restricted conditions (Singh, 2001). It also indicates the extent to which proteins can be incorporated into aqueous food formulations. The result indicated that cassava-pigeon pea composite flour could serve well where moisture absorption is key to the food production, like in bakeries. High oil absorption capacity indicates the lipophilic character of the components of the flours (Ubbor and Akobundu, 2009). It is a vital quality of a raw material that reflects on the mouthfeel of the final product. The oil absorption capacity of the composite flour could therefore be of advantage in food formulations. Swelling capacity of flours is often related to their starch and protein contents (Woolfe, 1992). This may explain why sample A had the highest swelling capacity (1.96\%). Incorporation of pigeon pea respectively led to reduction and increase in carbohydrate and protein contents thus lower swelling capacity.

Journal of the Faculty of Agriculture and Veterinary Medicine, Imo State University Owerri website: wwwajol.info 
Antinutrient contents of the flour blends. Sample A had the highest concentration of phytate $(0.321 \%)$, phenol $(0.107 \%)$, tannin $(0.243 \%)$ and $\mathrm{HCN}(3.18 \mathrm{mg} / \mathrm{kg})$ while sample E contained the least value of phytate $(0.253 \%)$, phenol $(0.071 \%)$, tannin $(0.130 \%)$ and $\mathrm{HCN}(2.04 \mathrm{mg} / \mathrm{kg})$ (Table 4). The trend indicated that the level of these antinutrients decreased with corresponding increase in pigeon pea flour addition except for trypsin inhibitor. It was observed that addition of more legume (pigeon pea) led to higher level of trypsin inhibitor in the composite flour. On the contrary, sample A contained the least concentration of trypsin inhibitor $(0.39 \mathrm{TIU} / \mathrm{mg})$ while sample E had the highest (1.30TIU/mg). The thermal destruction of these antinutrients especially $\mathrm{HCN}$, during food processing (e.g. boiling, baking, etc) has earlier been reported (Ihemeje et al., 2010; Satinder et al., 2015).

\section{Sensory attributes of the cookie samples}

The mean scores of the attributes for each sample is shown in Table (5). The statistical analysis on the sensory scores indicated that there was significant $(\mathrm{p}<0.05)$ difference among the samples in terms of colour, but there was no significant difference $(\mathrm{p}<0.05)$ in aroma, mouth feel, taste and overall acceptability.

\section{Physical characteristics of the cookies}

There was significant $(\mathrm{p}<0.05)$ difference between cookies made from $100 \%$ cassava flour and flour blends in terms of diameter and thickness (Table 6). The diameter and thickness of the cookies increased slightly as the proportion of pigeon pea flour increased in the blends. The increases in diameter and thickness cookies were added advantages as such properties could attract higher prices at the market. However, there was insignificant $(p>0.05)$ decrease in weight of cookies made from composite flours as the proportion of pigeon pea flour increased. This may be due to the low bulk density of the pigeon pea flour. The spread ratio of the cookie samples $(1.058-1.095)$ also showed a slight decrease as the proportion of pigeon pea flour increased.

\section{CONCLUSION}

The result of this work showed that substitution of cassava flour with pigeon pea flour increased most of the nutrients in the flour such as protein, ash and fat contents. Therefore, the composite flour can be adopted or used in baking to prevent protein energy malnutrition in the community. The sensory evaluation revealed that cookies produced from all the blends were appreciated by the panelists but those made from 5\% and 10\% levels of substitution with pigeon pea flour had higher overall acceptability.

\section{Recommendation}

The utilization of cassava-pigeon pea composite flour in the production of cookies is thus recommended as it leads to improved nutrient composition and acceptable organoleptic attributes. The inclusion of pigeon pea flour to other tubers or cereal flours for the production of bakery products should also be encouraged.

Journal of the Faculty of Agriculture and Veterinary Medicine, Imo State University Owerri website: wwwajol.info 


\section{REFERENCES}

Abbey, B. W. and Ibeh, G. O. (1998). Functional properties of raw and processed cowpea (Vignaunguiculata, Walp) flours. J. Food Sci., 53:1975-1991.

Amaefule, K. U., Ironkwe, M. C. and Ojewola, G. S. (2006).Pigeon pea (Cajanuscajan) seed meal as protein source for pullets: Performance of grower pullets fed raw or processed pigeon pea seed meal diets. International Journal of Poultry Science, 5(1): 60 - 64.

AOAC (2010). Official Method of Analysis. Association of Official Analytical Chemists. $7^{\text {th }}$ Edition, Washington, D.C. pp. 800-835.

Abdel, R.., Sirelkhatim, M. E., Ali, O. A. and Rea, H. (2010). The Chemical Composition of Pigeon Pea (Cajanuscajana) Seed and Functional Properties of Protein Isolate. Pakistan Journal of Nutrition, 9: 1069-1073.

Balagopalan, C., Padmaja, G., Nanda, S.K. and Moorthy, S.M. (1988). Cassava in food, feed and industry. CRC Press, Boca Raton, Florida, USA, p. 205.

Beuchat, L. R. (1977). Functional and electrophoretic characteristics of succinylated peanut flour proteins. J. Agric. and Food Chem., 25; 258-260.

Berghofer, E. (2000).BrotalsfunktionalesLebensmittel. GetreideMehlBrot, 54(3): 175-179.

Bugusu, B.A., Campanella, O. and Hamaker, B. R. (2001). Improvement of sorghum-wheat composite dough rheological properties and breadmaking quality through zein addition. Cereal Chemistry 78(1): 31-35.

Echendu, C.A., Onimawo, I. A. and Somtochi, A. (2004). Production and evaluation of doughnuts and biscuits from maize- pigeon pea Flour Blends. Nigeria Food Journal, 22: $147-153$.

Enwere, N.J. (1998). Foods of Plant Origin, Afro-Orbis Publishers, Nsukka, Nigeria, 1st Edition, pp. 137-249.

FAO (1990).Roots, tubers, plantains and bananas in human nutrition.FAO, Rome, Italy.

Giami, S. Y. (1993). Effect of processing on the functional properties of cowpea (Vignaunguiculata) flour. Food Chem., 47:153 - 158.

Gomez, M.I., Obilana, A.B., Martin, D.F., Madzvanuse, M. and Manyo, E.S. (1997). Practical manual of laboratory procedures for quality evaluation of sorghum and pearl millet. International Crops Research Institute for the Semi-Arid Tropics (ICRISAT), India. 
Ihemeje, A. Okorie, S. U. and Ekwe, C. C. (2010). Effects of processing methods on biochemical, functional and anti-nutritional properties of African walnut (Tetracarpidiumconophorum), J. Biol. Sci. Bioconv., 4: 55 - 64.

Kulkarni, S.D. (1994). Roasted soybean in cookies influence on product quality.Journal of Food Science and Technology, 34: 503-505.

Okpala, L. C. and Mamah, E. N. (2001). Functional properties of raw and processed pigeon pea (Cajanuscajan) flour. Int. J. Food Sci. Nutr., 52(4):343-346.

Olu, M., Ogunmoyela, O.A., Oluwajoba, S.O., Olurin, T.O. and Ogundipe, M.R. (2011). The development of whole wheat dough meal enriched with soyabeans. International Research Journal ofBiochemistry and Bioinformants, 1 (10): 266-274.

Onwuka, G.I. (2005). Food Analysis and Instrumentation, Theory and Practice. Naphtali Prints, Lagos, Nigeria. pp. 64-76.

Oyewole, O.B., Sanni, L.O. and Ogunjobi, M.A. (1996). Production of biscuit from cassava flour. Nigerian Food Journal, 14: 25-30.

Pearson, D. (1976). The Chemical Analysis of Foods, $2^{\text {nd }}$ edition, Longman Group Ltd. Edinburgh, London and New York, p. 536.

Salazar, J., Valasquez, R., Quesada, S., Pincineli, A.L. and Rastreli, L. (2006). Chemical composition and anti-nutritional factors of lycianthessynanthera leaves. Food Chemistry Journal, 97 (3): 342-448.

Satinder, K., Savita, S., Baljit, S. and Dar, B. N. (2015). Effect of extrusion variables (temperature, moisture) on the antinutrient components of cereal brans. J. Food Sci. Technol. 52(3): 1670- 1676.

Shittu, T., Raji, A. O. and Sanni, L. O. (2007). Bread from composite cassava-wheat flour: I. Effect of baking time and temperature on some physical properties of bread loaf. Food Research International, 40: 280-290.

Singh, U. (2001). Functional properties of grain legume flour. Journal of Food Science and Technology, 38: 191-199.

Smith, C., Megan, W. V., Twaalfhoven, L. and Hitchcock, C. (1980). The determination of trypsin inhibitor levels in food stuffs. Journal of the Science of Food and Agriculture, 31: 341-350.

Journal of the Faculty of Agriculture and Veterinary Medicine, Imo State University Owerri website: wwwajol.info 
Torres, A., Frias, J., Granito, M. and Vidal-Valverde, C. (2007). Germinated Cajanuscajanseeds as ingredients in pasta products: Chemical, biological and sensory evaluation. Food Chemistry, 101: 202-211.

Ubbor, S. C. and Akobundu, E. N. T. (2009). Quality characteristics of cookies from composite flour of watermelon seeds cassava and wheat. Pakistan Journal of Nutrition, 8: 10971102.

Ukpabi, U. J. and Ndimele, C. (1990). Evaluation of gari production in Imo State, Nigeria. Nig. Food J., 8: 105-110.

Woolfe, J. (1992). Sweet Potato: An Untapped Food Resource. Cambridge University Press, pp. 1-13, 366-367. 
Journal of Agriculture and Food Sciences Ihemeje A, Uneanya G.C., Odimegwu N.E. and Echefu E.O. Volume 15 Numberl, April 2017 pp. 43 - 53.

\section{APPENDIX}

TABLE 1: Recipe for cookies production

\begin{tabular}{lc}
\hline Ingredient & weight(g) \\
\hline Flour & 200 \\
Fat & 15 \\
Sugar & 25 \\
Powder milk & 15 \\
Salt & 2 \\
\hline
\end{tabular}

Table 2. Proximate composition of cassava-pigeon pea flour samples

\begin{tabular}{llcllll}
\hline $\begin{array}{l}\text { SAMPLE } \\
\text { (CF:PPF) }\end{array}$ & $\begin{array}{l}\text { CRUDE } \\
\text { PROTEIN(\%) }\end{array}$ & FAT (\%) & $\begin{array}{l}\text { CRUDE } \\
\text { FIBRE } \\
(\%)\end{array}$ & ASH(\%) & $\begin{array}{l}\text { MOISTURE } \\
\text { CONTENT } \\
(\%)\end{array}$ & CHO(\%) \\
\hline & & & & & & \\
A (100:0) & $2.19^{\mathrm{e}} \pm 0.03$ & $1.09^{\mathrm{e}} \pm 0.04$ & $4.66^{\mathrm{a}} \pm 0.06$ & $1.49^{\mathrm{d}} \pm 0.03$ & $11.03^{\mathrm{a}} \pm 0.03$ & $79.99^{\mathrm{a}} \pm 0.08$ \\
B (95:5) & $2.72^{\mathrm{d}} \pm 0.02$ & $1.21^{\mathrm{d}} \pm 0.04$ & $4.49^{\mathrm{b}} \pm 0.02$ & $1.67^{\mathrm{cd}} \pm 0.04$ & $10.89^{\mathrm{ab}} \pm 0.06$ & $79.29^{\mathrm{b}} \pm 0.04$ \\
C (90:10) & $3.52^{\mathrm{c}} \pm 0.12$ & $1.43^{\mathrm{c}} \pm 0.03$ & $4.27^{\mathrm{c}} \pm 0.04$ & $1.80^{\mathrm{c}} \pm 0.01$ & $10.79^{\mathrm{b}} \pm 0.07$ & $78.14^{\mathrm{c}} \pm 0.01$ \\
D (85:15) & $5.19^{\mathrm{b}} \pm 0.01$ & $1.69^{\mathrm{b}} \pm 0.05$ & $4.10^{\mathrm{d} \pm 0.03}$ & $2.20^{\mathrm{b}} \pm 0.06$ & $10.64^{\mathrm{c}} \pm 0.03$ & $75.88^{\mathrm{d}} \pm 0.01$ \\
E (80:20) & $7.25^{\mathrm{a}} \pm 0.06$ & $1.91^{\mathrm{a}} \pm 0.06$ & $3.76^{\mathrm{e}} \pm 0.08$ & $2.52^{\mathrm{a}} \pm 0.04$ & $10.58^{\mathrm{c}} \pm 0.05$ & $73.50^{\mathrm{e}} \pm 0.12$ \\
LSD & 0.20 & 0.17 & 0.17 & 0.20 & 0.15 & 0.22 \\
\hline
\end{tabular}

Values are means of triplicate analysis and standard deviation. Means on the same column with the same superscript are not significantly $(\mathrm{p}<0.05)$ different.

KEY: CF- Cassava Flour PPF- Pigeon Pea Flour

Journal of the Faculty of Agriculture and Veterinary Medicine, Imo State University Owerri website: www ajol.info 
Journal of Agriculture and Food Sciences Ihemeje A, Uneanya G.C., Odimegwu N.E. and Echefu E.O. Volume 15 Numberl, April 2017 pp. 43 - 53.

Table 3. Functional properties of flour samples

\begin{tabular}{llllll}
\hline $\begin{array}{l}\text { SAMPLES } \\
(\text { CF:PPF })\end{array}$ & $\begin{array}{l}\text { BULK } \\
\text { DENSITY } \\
(\mathrm{g} / \mathrm{ml}))\end{array}$ & $\begin{array}{l}\text { WAC } \\
(\mathrm{g} / \mathrm{g})\end{array}$ & $\begin{array}{l}\text { OAC } \\
(\mathrm{g} / \mathrm{g})\end{array}$ & $\begin{array}{l}\text { SWELLING } \\
\text { CAPACITY }(\%)\end{array}$ & $\begin{array}{l}\text { FOAMING } \\
\text { CAPACITY } \\
(\%)\end{array}$ \\
\hline & & & & & \\
& & & & & \\
A (100:0) & $0.608^{\mathrm{a}} \pm 0.01$ & $2.11^{\mathrm{a}} \pm 0.02$ & $2.11^{\mathrm{a}} \pm 0.06$ & $1.96^{\mathrm{a}} \pm 0.03$ & $11.71^{\mathrm{d}} \pm 0.13$ \\
$\mathrm{~B}(95: 5)$ & $0.578^{\mathrm{a}} \pm 0.003$ & $2.00^{\mathrm{a}} \pm 0.05$ & $2.05^{\mathrm{a}} \pm 0.03$ & $1.92^{\mathrm{a}} \pm 0.01$ & $12.28^{\mathrm{a}} \pm 0.14$ \\
$\mathrm{C}(90: 10)$ & $0.555^{\mathrm{a}} \pm 0.004$ & $1.87^{\mathrm{b}} \pm 0.02$ & $1.98^{\mathrm{b}} \pm 0.02$ & $1.89^{\mathrm{a}} \pm 0.02$ & $13.95^{\mathrm{b}} \pm 0.13$ \\
D (85:15) & $0.542^{\mathrm{a}} \pm 0.002$ & $1.81^{\mathrm{c}} \pm 0.02$ & $1.92^{\mathrm{cd}} \pm 0.02$ & $1.78^{\mathrm{b}} \pm 0.03$ & $14.31^{\mathrm{a}} \pm 0.06$ \\
E (80:20) & $0.531^{\mathrm{a}} \pm 0.01$ & $1.79^{\mathrm{c}} \pm 0.08$ & $1.83^{\mathrm{d}} \pm 0.05$ & $1.68^{\mathrm{c}} \pm 0.04$ & $14.64^{\mathrm{a}} \pm 0.07$ \\
LSD & 0.20 & 0.15 & 0.10 & 0.10 & 0.34 \\
\hline
\end{tabular}

Values are means of triplicate analysis and standard deviation. Means on the same column with the same superscript are not significantly different $(p>0.05)$

KEY: CF- Cassava Flour, PPF: Pigeon Pea Flour

Table 4. Antinutrient Composition of the Flour Samples

\begin{tabular}{lcccll}
\hline $\begin{array}{l}\text { SAMPLES } \\
(\mathrm{CF}: \text { PPF })\end{array}$ & $\begin{array}{c}\text { PHYTATE } \\
(\%)\end{array}$ & $\begin{array}{c}\text { PHENOL } \\
(\%)\end{array}$ & $\begin{array}{c}\text { TANNIN } \\
(\%)\end{array}$ & $\begin{array}{l}\text { TRYPSIN } \\
\text { INHIBITOR(TIU/mg) }\end{array}$ & $\begin{array}{l}\text { HCN } \\
(\mathrm{mg} / \mathrm{kg})\end{array}$ \\
\hline A (100:0) & $0.321^{\mathrm{a}} \pm 0.004$ & $0.107^{\mathrm{a}} \pm 0.005$ & $0.243^{\mathrm{a}} \pm 0.006$ & $0.39^{\mathrm{e}} \pm 0.03$ & $3.18^{\mathrm{a}} \pm 0.07$ \\
B (95:5) & $0.311^{\mathrm{b}} \pm 0.007$ & $0.098^{\mathrm{ab}} \pm 0.005$ & $0.207^{\mathrm{b}} \pm 0.002$ & $0.61^{\mathrm{d}} \pm 0.02$ & $2.86^{\mathrm{b}} \pm 0.06$ \\
C (90:10) & $0.294^{\mathrm{c}} \pm 0.002$ & $0.086^{\mathrm{ab}} \pm 0.001$ & $0.170^{\mathrm{c}} \pm 0.002$ & $0.77^{\mathrm{c}} \pm 0.01$ & $2.53^{\mathrm{c}} \pm 0.03$ \\
D (85:15) & $0.275^{\mathrm{d}} \pm 0.003$ & $0.072^{\mathrm{b}} \pm 0.005$ & $0.143^{\mathrm{d}} \pm 0.003$ & $1.00^{\mathrm{b}} \pm 0.06$ & $2.21^{\mathrm{d}} \pm 0.03$ \\
E (80:20) & $0.253^{\mathrm{e}} \pm 0.005$ & $0.071^{\mathrm{b}} \pm 0.001$ & $0.130^{\mathrm{e}} \pm 0.002$ & $1.30^{\mathrm{a}} \pm 0.07$ & $2.04^{\mathrm{e}} \pm 0.03$ \\
LSD & 0.00 & 0.03 & 0.00 & 0.10 & 0.15 \\
\hline
\end{tabular}

Values are means of triplicate analysis and standard deviation. Means on the same column with the same superscript are not significantly different $(p>0.05)$

KEY: CF- Cassava Flour

PPF- Pigeon Pea Flour

Journal of the Faculty of Agriculture and Veterinary Medicine, Imo State University Owerri website: $w w w$ ajol.info 
Journal of Agriculture and Food Sciences Ihemeje A, Uneanya G.C., Odimegwu N.E. and Echefu E.O. Volume 15 Numberl, April 2017 pp. 43 - 53.

Table 5. Sensory characteristics of cookie samples produced from cassava-pigeon pea composite flour blends

Values are means of triplicate analysis and standard deviation. Means in the same column with

\begin{tabular}{lllllll}
\hline $\begin{array}{l}\text { SAM } \\
\text { PLE }\end{array}$ & $\begin{array}{l}\text { COLO } \\
\text { UR }\end{array}$ & $\begin{array}{l}\text { ARO } \\
\text { MA }\end{array}$ & $\begin{array}{l}\text { MOUTHF } \\
\text { EEL }\end{array}$ & $\begin{array}{l}\text { CRISPINE } \\
\text { SS }\end{array}$ & $\begin{array}{l}\text { TAS } \\
\text { TE }\end{array}$ & $\begin{array}{c}\text { OVERALL } \\
\text { ACCEPTABI } \\
\text { LITY }\end{array}$ \\
\hline A & $6.53^{\mathrm{a}}$ & $5.60^{\mathrm{a}}$ & $6.10^{\mathrm{a}}$ & $5.50^{\mathrm{a}}$ & $6.40^{\mathrm{a}}$ & $5.83^{\mathrm{a}}$ \\
$\mathrm{B}$ & $6.93^{\mathrm{a}}$ & $5.73^{\mathrm{a}}$ & $6.00^{\mathrm{a}}$ & $6.17^{\mathrm{a}}$ & $6.73^{\mathrm{a}}$ & $6.37^{\mathrm{a}}$ \\
$\mathrm{C}$ & $6.43^{\mathrm{b}}$ & $5.87^{\mathrm{a}}$ & $6.00^{\mathrm{a}}$ & $6.10^{\mathrm{a}}$ & $6.53^{\mathrm{a}}$ & $5.93^{\mathrm{a}}$ \\
$\mathrm{D}$ & $6.40^{\mathrm{a}}$ & $6.10^{\mathrm{a}}$ & $5.73^{\mathrm{a}}$ & $5.30^{\mathrm{a}}$ & $6.30^{\mathrm{a}}$ & $5.70^{\mathrm{a}}$ \\
$\mathrm{E}$ & $6.38^{\mathrm{a}}$ & $6.00^{\mathrm{a}}$ & $5.60^{\mathrm{a}}$ & $5.20^{\mathrm{a}}$ & $6.13^{\mathrm{a}}$ & $5.43^{\mathrm{a}}$ \\
& 0.67 & 0.82 & 1.10 & 1.22 & 0.90 & 0.98 \\
\hline
\end{tabular}

LSD

the same superscript are not significantly $(\mathrm{p}<0.05)$ different.

KEY: $\mathbf{A}=$ Cookies made from $100 \%$ cassava flour

$\mathbf{B}=$ Cookies made from $95 \%$ cassava flour $+5 \%$ pigeon pea flour

$\mathbf{C}=$ Cookies made from $90 \%$ cassava flour $+10 \%$ pigeon pea flour

$\mathbf{D}=$ Cookies made from $85 \%$ cassava flour $+15 \%$ pigeon pea flour

$\mathbf{E}=$ Cookies made from $80 \%$ cassava flour $+20 \%$ pigeon pea flour

Table 6. Physical characteristics of cookies produced from cassava-pigeon pea flour blends

\begin{tabular}{lcccc}
\hline SAMPLES & $\begin{array}{c}\text { WEIGHT } \\
(\mathrm{g})\end{array}$ & $\begin{array}{c}\text { DIAMETER } \\
(\mathrm{mm})\end{array}$ & $\begin{array}{c}\text { THICKNESS } \\
(\mathrm{mm})\end{array}$ & $\begin{array}{l}\text { SPREAD } \\
\text { RATIO }\end{array}$ \\
\hline & & & & \\
$\mathrm{A}$ & $7.05^{\mathrm{a}} \pm 0.02$ & $37.00^{\mathrm{a}} \pm 0.00$ & $33.80^{\mathrm{a}} \pm 0.12$ & $1.095^{\mathrm{a}} \pm 0.27$ \\
$\mathrm{~B}$ & $6.80^{\mathrm{a}} \pm 0.04$ & $36.10^{\mathrm{a}} \pm 0.01$ & $34.13^{\mathrm{a}} \pm 0.08$ & $1.058^{\mathrm{a}} \pm 0.14$ \\
$\mathrm{C}$ & $6.73^{\mathrm{a}} \pm 0.01$ & $36.21^{\mathrm{a}} \pm 0.07$ & $34.30^{\mathrm{a}} \pm 0.02$ & $1.055^{\mathrm{a}} \pm 0.11$ \\
$\mathrm{D}$ & $6.51^{\mathrm{a}} \pm 0.03$ & $36.42^{\mathrm{a}} \pm 0.01$ & $34.36^{\mathrm{a}} \pm 0.05$ & $1.060^{\mathrm{a}} \pm 0.08$ \\
$\mathrm{E}$ & $6.38^{\mathrm{a}} \pm 0.02$ & $36.50^{\mathrm{a}} \pm 0.03$ & $34.48^{\mathrm{a}} \pm 0.01$ & $1.059^{\mathrm{a}} \pm 0.07$ \\
LSD & 1.20 & 1.54 & 1.83 & 1.01 \\
\hline
\end{tabular}

Values are means of triplicate analysis and standard deviation. Means in the same column with the same superscript are not significantly $(\mathrm{p}<0.05)$ different.

KEY: $\mathbf{A}=$ Cookies made from $100 \%$ cassava flour

$\mathbf{B}=$ Cookies made from $95 \%$ cassava flour $+5 \%$ pigeon pea flour

$\mathbf{C}=$ Cookies made from $90 \%$ cassava flour $+10 \%$ pigeon pea flour

$\mathbf{D}=$ Cookies made from $85 \%$ cassava flour $+15 \%$ pigeon pea flour

$\mathbf{E}=$ Cookies made from $80 \%$ cassava flour $+20 \%$ pigeon pea flour

Journal of the Faculty of Agriculture and Veterinary Medicine, Imo State University Owerri website: www ajol.info 